" much of that expansion has been on ill-considered lines and neglectful of the proposals made by the Government of India previously to the reforms". Education, as a transferred subject, is now in the hands of ministers in the provinces. A tribute is paid to the zeal and ability which these ministers bring to bear upon their task. But the position of a minister is unstable. He cannot easily escape from adverse influences. It was represented to the Committee that in some provinces he had exercised pressure on the Director of Public Instruction in the matter of appointments and promotions on political and irrelevant personal grounds. Moreover, he has to worl through various agencies, such as local bodies, which, the report notes as a distressing feature, "have in many instances gravely abused their powers for political and other purposes". $\mathrm{He}$ is likewise largely dependent on the services which deal directly with education. The Indian Educational Service, "with its fine traditions of integrity and devotion to duty ", is moribund. The Committee declares that its progressive extinction, accompanied by the failure to reconstitute the provincial Services, "has been disastrous to the organisation of Indian education". " The number of fully qualified men and women, competent to hold the higher posts in the Department, has become totally inadequate in every province."

The attitude of the Committee has clearly been sympathetic. But the studied restraint of the report serves to emphasise some of the conclusions into which facts have forced its members. If literacy is a desirable qualification in the voter, an expansion of mass education which is (in the words of the report) "so largely ineffective as scarcely to influence the advance of literacy at all in the sense of increasing the proportion of literates to the population" cannot result in the formation of a competent electorate. Nor, however brilliant may be the exceptional scholar, does a top-heavy superstructure of higher education, coupled with relaxation of the standards of admission and too often with unemployment after completion of the course, promise well for the production of sound representatives and officials. Above all, this narrative of educational work during the past few years indicates a fatal tendency to loosen the framework on which the whole fabric depends for support.

H. SHARP.

\title{
Bochart de Saron, I730-I794.
}

$\mathrm{W}$ HEN Herschel, in April 1781, announced the appearance of a new body in the heavens, nowhere did the news create greater interest than in France, where Lalande, Mechain, Lemonnier, Laplace, and Bochart de Saron attempted to discover the orbit in which the body moved. Based on the supposition that it was a comet, the investigations all failed until Bochart de Saron, on May 8, 1781, announced that the so-called comet was in reality much farther from the sun than had been thought. This was the first glimmering of light on the perplexing subject which eventually led to the discovery that Herschel's ' comet' was a new planet, to which he assigned the name Georgium Sidus, but was afterwards designated Uranus.

Jean-Baptiste-Gaspard Bochart de Saron, born on Jan. 16, 1730, two hundred years ago, was as distinguished in law as in science. He served as president of the Parliament of Paris, and at his seat in Champagne had an observatory partly furnished by Ramsden. It is said, also, that a duplicate of Ramsden's dividing machine was introduced into France by him, concealed in the pedestal of a table. Especially interested in comets, he became a member of the Paris Academy of Sciences, and it was he who paid for the printing, in 1784, of Laplace's "Théorie du mouvement et de la figure des planètes". But, ten years later, neither his eminence as an astronomer or as a lawyer could save him from the fury of the Terror, and he perished beneath the guillotine.

The king had fallen in January 1793, Marie Antoinette in October; the academies had all been suppressed, the scaffold had alike claimed Bailly, Madame Roland, and Danton, and executions could be counted by the hundred. On April 13, 1794, nineteen were condemned, on April 18 a further seventeen, mostly of the nobility, and on April 20, Bochart de Saron and twenty-four of his fellow ex-presidents and counsellors of the Parliaments of Paris and Toulouse suffered. It was to see this ' batch' tried that the Auvergnat carpenter, Trinchard, wrote the invitation, "If you are not alone and the journeyman is working, you can, my dear wife, come to the court to see twenty-four gentlemen, all of them former presidents or counsellors . . . passed in judgment. I advise you to get something to eat before coming, as we shall not have finished before three o'clock."

There was never any doubt of the finding of the court, and while it was still sitting Fouquier was ordering the tumbrils and the escort. Presiding over the court which condemned Bochart de Saron was the notorious Coffinhal, who a few days later, when trying the Farmers-General, immortalised himself by replying to the great Lavoisier, who had asked for a delay in order to allow him to conclude an experiment, "The Republic requires neither savants nor chemists; the course of justice cannot be suspended". For three months longer the guillotine continued to rob France of some of her greatest minds. With the fall of Robespierre on July 28, the nation breathed again, and the year which saw the death of Condorcet, Bochart de Saron, and Lavoisier, also saw the foundation of the great institutions, the École Normale, the École Polytechnique, and the Conservatoire des Arts et Métiers, while the year 1795 saw the inauguration of the famous Institut de France.

No. 3142 , VoL. 125] 